\title{
LETTER
}

\section{Use of carperitide infusion for acutely decompensated heart failure}

\author{
Yoshihisa Morita*1, Shun Kohsaka², Kazuki Oshima², Tsutomu Yoshikawa ${ }^{3}$ and Keiichi Fukuda² \\ See related research by Mitaka et al., http://ccforum.com/content/15/5/R258
}

Mitaka and colleagues [1] recently reported in their meta-analysis that carperitide infusion improved the renal function of cardiovascular surgical patients, and we feel that this notion could be expanded to medical patients, particularly with the use of carperitide. Although some studies have not been able to recommend the use of nesiritide in acute heart failure (HF) patients $[2,3]$, more recent clinical trials have demonstrated a favorable effect of carperitide on ventricular remodeling and neurohormonal systems $[4,5]$.

In our own series of acute HF patients $(\mathrm{N}=371)$, carperitide was given to 135 patients (36.4\%) and it was more frequently used in patients with higher New York Heart Association functional class (30.4 versus 15.7\%, $P<0.01)$, prominent signs of HF, such as S3 heart sound (65.4 versus $50.9 \%, P<0.01$ ), pulmonary rales $(67.2$ versus $31.3 \%, P<0.01)$, jugular venous distention (49.6 versus $34.7 \%, P<0.01)$, and lower extremity edema (64.1 versus $48.2 \%, P<0.01$ ).

In agreement with the analysis performed by Mitaka and colleagues, patients on carperitide had a higher rate of improvement in functional class (96.0 versus $67.9 \%$, $P<0.01)$ during the hospital course. Importantly, there was no worsening of the mortality and/or HF rehospitalization rate in the carperitide treatment group compared to the non-carperitide group (29.1 versus $25.4 \%, P=0.29$ ) during the mean follow-up period of 1.7 years. Further, the use of carperitide was not associated with adverse events after adjustment for known predictors of HF, such as hypertension, diabetes, hyperlipidemia, chronic kidney disease, and brain natriuretic peptide level at discharge (hazard ratio 1.13; $P=0.59$ ).

Carperitide compares favorably to nesiritide in several ways; it has a shorter half-life (2 minutes), does not mandate bolus infusion, and is used mostly as a single

\footnotetext{
*Correspondence: armlegstrong2002@yahoo.co.jp

'Department of Anesthesiology and Critical Care, University of Miami Miller School of Medicine, Jackson Memorial Hospital, 1611 NW 12th Avenue, Miami, FL, USA

Full list of author information is available at the end of the article
}

agent, not as an add-on drug to diuretics. We thus surmise that these unique pharmacological profiles may lead to different outcomes and the use of carperitide should be judiciously evaluated in prospective trials.

\section{Abbreviations \\ HF, heart failure.}

\section{Competing interests}

The authors declare that they have no competing interests

\section{Author details}

'Department of Anesthesiology and Critical Care, University of Miami Miller School of Medicine, Jackson Memorial Hospital, 1611 NW 12th Avenue, Miami, FL, USA. ${ }^{2}$ Department of Cardiology, Keio University School of Medicine, 35 Shinanomachi Shinjuku Tokyo Japan. ${ }^{3}$ Sakakibara Heart Institute, 3-16-1 Asahicho Fuchu Tokyo Japan.

Published: 25 January 2012

\section{References}

1. Mitaka C, Kudo T, Haraguchi G, Tomita M: Cardiovascular and renal effects of carperitide and nesiritide in cardiovascular surgery patients: a systematic review and meta-analysis. Crit Care 2011, 15:R258.

2. O'Connor CM, Starling RC, Hernandez AF, Armstrong PW, Dickstein K, Hasselblad V, Heizer GM, Komajda M, Massie BM, McMurray JJ, Nieminen MS, Reist CJ, Rouleau JL, Swedberg K, Adams KF Jr, Anker SD, Atar D, Battler A, Botero R, Bohidar NR, Butler J, Clausell N, Corbalán R, Costanzo MR, Dahlstrom U, Deckelbaum LI, Diaz R, Dunlap ME, Ezekowitz JA, Feldman D, et al.: Effect of nesiritide in patients with acute decompensated heart failure. NEngl J Med 2011, 365:32-43. Erratum in N Engl J Med 2011, 365:773.

3. Sackner-Bernstein JD, Skopicki HA, Aaronson KD: Risk of worsening renal function with nesiritide in patients with acutely decompensated heart failure. Circulation 2005, 111:1487-1491.

4. Hata N, Seino Y, Tsutamoto T, Hiramitsu S, Kaneko N, Yoshikawa T, Yokoyama H, Tanaka K, Mizuno K, Nejima J, Kinoshita M: Effects of carperitide on the long-term prognosis of patients with acute decompensated chronic heart failure: the PROTECT multicenter randomized controlled study. Circ J 2008, 144:1102-1108.

5. Sezai A, Hata M, Niino T, Yoshitake I, Unosawa S, Wakui S, Fujita K, Takayama T, Kasamaki Y, Hirayama A, Minami K: Continuous low-dose infusion of human atrial natriuretic peptide in patients with left ventricular dysfunction undergoing coronary artery bypass grafting: NU-HIT (Nihon University working group study of low-dose Human ANP Infusion Therapy during cardiac surgery) for left ventricular dysfunction. J Am Coll Cardio/ 2010, 55:1844-1851.

\section{doi:10.1186/cc10606}

Cite this article as: Morita Y, et al.: Use of carperitide infusion for acutely decompensated heart failure. Critical Care 2012, 16:406. 